\title{
Pathological

\section{Association of adiponectin gene polymorphism and its levels with Hepatitis B Virus related disease in the population of Assam, India}

\author{
Namrata Kumari*1, Bhavadev Goswami ${ }^{2}$, Manab Deka ${ }^{1}$, Priyanka Kashyap ${ }^{1}$, Morteza \\ Kordafshari ${ }^{1}$ and Majid Khandouzi ${ }^{1}$ \\ ${ }^{1}$ Department of Bioengineering and Technology, Gauhati University, Guwahati, Assam \\ ${ }^{2}$ Department of Gastroenterology, Gauhati Medical College, Guwahati, Assam
}

\begin{abstract}
Despite the important role of adiponectin in the progression of pathogenesis of liver cirrhosis, few data have been collected from the patients with different stages of liver diseases related to hepatitis B virus infection. We have studied the role of adiponectin in hepatitis B patients. Experiments were conducted an OPD-based cross-sectional study in a tertiary care hospital Assam, India which is a HBV-endemic country. A total of 220HBV-infected individuals and 110 healthy controls, were assessed for serum adiponectin levels which were quantified by enzyme-linked immunosorbent assay. Serum HBV viral load and markers, serum alanine aminotransferase levels and metabolic factors and also the single nucleotide polymorphism of Adiponectin were analysed. Adiponectin levels were found to be associated with the chronic HBV infection ( $\mathrm{p}<0.05)$. The presence of HBV infection was found to be positively associated with serum adiponectin levels $(\mathrm{P}<0.0001)$.Out study has also reported that allele TG of SNPrs2241766 ( $<<0.05,0 R=2.03), G T$ of rs 1501299 $(p<0.05,0 R=1.78)$ and CG of SNPrs266729 $(\mathrm{p}<0.05,0 R=2.11)$ has a significant effect on this disease. Study findings were also expressed that, the serum adiponectin levels were positively associated with HBV viral load in overweight to HBV-infected subjects $(\mathrm{p}<0.05)$. The quantitative value of adiponectin was found higher in those patients with viral load of about $200 \times 103-200 \times 106 \log$ copies $/ \mathrm{ml}$. Although the chronic HBV-infected individuals were more severe than the healthy controls, they were found as significantly higher serum adiponectin levels than healthy persons. Also it was found that the adiponectin levels were positively associated with HBV viral load in overweight to obese HBV-infected subjects.It is now possible to suggest that serum adiponectin may have a role in the progression in fibrosis in $\mathrm{CHB}$ infection.
\end{abstract}

KEY WORDS: HEPATITIS B VIRUS, CHRONIC HEPATITIS B, TOTAL BILIRUBIN

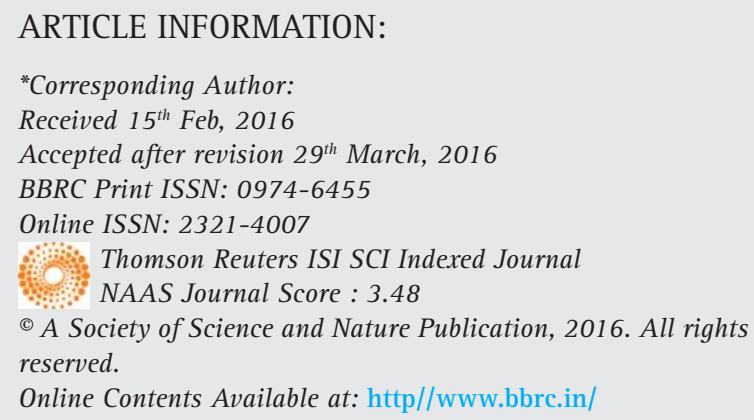




\section{INTRODUCTION}

Hepatitis B virus infection is said to be one of the major public health related problems worldwide which is affecting approximately 350 million persons and out of which about a third gradually develop severe HBV-related complications. The HBV is now a challenging global health related issue especially in the Asia Pacific region. Both the host and the viral factors are mainly said to be associated to the pathogenesis of HBV infection, which are known to contribute to the clinical outcomes of chronic HBV infection Liver diseases and liver cancer shows a marked worldwide geographic and ethnic distribution (Shields and Harris, 1991, Lee et al.,1997, Liu, Chen and Lai, 2003 and Golsaz and Shokri 2016).

However, it is important to note that the interactions between the hepatitis $B$ virus infection and the metabolic factors are still remain unknown till date. A large number of clinical studies has reported that the HBV infection is closely related to the development of diabetes, fatty liver and other metabolic diseases. Adiponectin is found to be one of the major host factors linked to liver diseases (Marra, 2009; Kaser, 2005), including viral hepatitis (Liu, 2009; Lu, 2009).

Obesity is also now considered as a major public health problem worldwide, with significant social and psychological dimensions that have afflicted increasingly younger individuals and different socioeconomic groups. It is one of the most important significant of many other chronic non-communicable diseases (NCD) which are significantly affect the mortality rate of many countries which include developing countries (Costa et al., 2011). Adiponectin is an adipocyte-secreted protein which has several important metabolic functions . The metabolic syndrome may also can cause the progression and pathogenesis of the disease in the patients with chronic hepatitis B (CHB) infected persons. Adipocytokines play an important role in the metabolism of lipid and viral liver disease progression. But, the interactions among the hepatitis B virus (HBV) infection and adipocytokines remain largely unknown (Hsu et al., 2015).

We carried out the investigation to find out the association of HBV infection with metabolic characteristics which is an important facor associated with the obesity in the patients with HBV-infection and non infection . Also, to know the associative role of HBV DNA level or viral load on the metabolic profiles were studied under this. Initially, to confirm this association of the metabolism, a case-control analysis of patients were carried out with and without HBV infection (Hsu et al., 2012 ) .

Adiponectin is considered recently as a described hormone which is mainly produced by the adipose tissue and it has proterties like anti-inflammatory, anti- diabetic, insulin-sensitizing .In addition, adiponectin hormone can also improve the level of hepatic insulin sensitivity and decrease the lipid accumulation profile in macrophages which has an anti-inflammatory effects. Adiponectin also exerts its effects by the binding to its two candidate adiponectin receptors like adipo R1, and adipo R2, (Berg, 2002; Pellme, 2003; Steppan, 2002; Tschritter, 2003).

The role of adiponectin in the liver disease like HBV infection is still somewhat controversial and still the research is going on. Previously, to confirm the associative role between adiponectin and the viral factors or liver injuries a few clinical data were reported (Kaser et al., 2005) . In our study we aimed to test the hypothesis about the impact of the presence of the HBV related liver disease on the serum adiponectin levels. To confirm this hypothesis we investigated the association of HBV infection with metabolic profiles in infected and nonHBVinfected subjects(case Vs control).

\section{MATERIAL AND METHODS}

The study enrolled the HBV infected persons which were confirmed for the HBV detective marker surface antigen (HBsAg) .The healthy controls were recruited from the O.P.D of Department of Gastroenterology Gauhati Medical College Hospital. All positive HBsAg cases were screened further for liver function tests and controls with no Obesity and HBsAg negative and antiHCV positive were included in this study. But patients excluded from this study were with the other Hepatitis infections(HAV, HCV, HEV),Wilson disease and alcoholic liver diseases(ALD).The exclusion criteria also included drug-abusers and also the men who consumed more than $140 \mathrm{~g}$ or women who consumed more than $70 \mathrm{~g}$ of alcohol per week .

The above criteria were fulfilled by 210 HBsAg-seropositive candidates who had visited in the 0.P.D of Gauhati Medical College Hospital (GMCH) were studied for the Adiponectin levels and its SNPs. The ratio of HBsAgpositive cases to controls were considered as $2: 1$. Which included a randomly collected 110 non-HBV-infected persons.

After the sample collection both the $210 \mathrm{HBsAg}$-positive cases and 110 healthy controls were agreed for the health examination and blood collection for the serological and biochemical investigations to confirm the inclusion and exclusion criteria .For the medical record they were also given their inform consent form for confirming their health and vital status. The study protocol and the investigation were approved by the Gauhati University Ethics Committee.

The body height and weight of both the cases and controls were measured and the body mass index (BMI) 
was calculated by using the formula bodyweight in kilograms divided by the body height in meters squared. According to the rule of World Health Organization (WHO),the criteria for the population of Asia the participants were classified as normal or underweight (BMI $<23 \mathrm{~kg} / \mathrm{m} 2$ ), overweight (BMI23-24.9 kg/m2), or obese (BMI25 kg/m2) (18). The serological tests included the serum HBsAg, serum antibody to hepatitis C virus(anti$\mathrm{HCV}$ ) and also the HAV-IgM to find out the presence of any confections and were determined via microparticle enzyme immunoassay (3rd generation) in the study center ans the serum samples from each subjects were stored at $-80^{\circledR} \mathrm{C}$ until it is used. The HBV viral load was measured by with Quigen real-time polymerase chain reaction assay, which detects an upper limit of $640,200,000$ copies $/ \mathrm{ml}$ and a lower limit of 35 copies $/ \mathrm{ml}$ (1 copy $/ \mathrm{ml} \mathrm{1/4} 0.1718 \mathrm{IU} / \mathrm{ml}$ ). Also the serum adiponectin levels (in $\mu \mathrm{g} / \mathrm{ml}$ ) were determined by using the Invitrogen ELISA kit according to the manufacturer's instructions.

In our study we have selected 3 SNPs in the adiponectin genes from published literature and the database of Single Nucleotide Polymorphism (dbSNP) at the NCBI website (http://www.ncbi.nlm.nih.gov/ SNP): rs2241766 $(+45 \mathrm{~T}>\mathrm{G})$, rs1501299 (+276G $>\mathrm{T})$, rs266729 $(11377 \mathrm{C}>\mathrm{G})$.

The statistical analysis wasdone by using the SPSS version 13.1 to confirm the association.For the descriptive analyses we calculated the values and were pre- sented as either a number (percent;\%) or mean \pm SD (standard deviation). Statistical significance levels were determined by two-tailed tests and considered the significant $\mathrm{P}$ value $<0.05(\mathrm{p}<0.05)$. The mean $\pm \mathrm{SD}$ value of adiponectin levels in the HBV-infected individuals and healthy controls were calculated and also the age, gender and BMI were further compared for the case and control. Furthermore, the association between adiponectin levels and HBV viral load was examined with multivariate linear regression analyses in the HBV infected individuals.

\section{RESULTS AND DISCUSSION}

The findings of demographic and biochemical analysis of about 210 consecutive middle-aged and normal weight male subjects included in this study with chronic hepatitis B are presented in Table1, which show the age as $33.2 \pm 8.1$ for diseased and $23.6 \pm 3.18$ for control cases, $(\mathrm{p}<0.05)$. The INR value for case and controls were recorded as $1.45 \pm 0.49$ and $1.12 \pm 0.51$ respectively. Also the LFT test values were recorded as $2.1 \pm 1.4 \mathrm{mg} / \mathrm{dL}$ (TBil); 5.8.1 $\pm 2.1 \mathrm{~g} / \mathrm{dl}$ (Albumin); 53.30 $\pm 19.56 \mathrm{U} / \mathrm{L}(\mathrm{ALT})$; $31.1 \pm 14.17 \mathrm{U} / \mathrm{L}$ (AST).The BMI values were calculated in case and control as $24.51 \pm 3.68$ and 22.14 \pm 2.11 . Mean and S.D of serum adiponectin were $10.58 \pm 5.5$ and $9.89 \pm 4.86$ respectively in both case and control. The Hgb,

\begin{tabular}{|c|c|c|c|}
\hline Factors & $\begin{array}{l}\text { HBV Infected } \\
\text { persons } \\
(n=210)\end{array}$ & $\begin{array}{l}\text { Healthy } \\
\text { controls } \\
(n=110)\end{array}$ & $P$ value \\
\hline Age (years) & $33.2 \pm 8.1$ & $23.6 \pm 3.18$ & $<0.0000001$ \\
\hline $\begin{array}{l}\text { Sex (n) } \\
\text { Male } \\
\text { Female }\end{array}$ & $\begin{array}{l}144(68.5 \%) \\
66(31.5 \%)\end{array}$ & $\begin{array}{l}68(61.8 \%) \\
42(38.2 \%)\end{array}$ & 0.262 \\
\hline INR & $1.45 \pm 0.49$ & $1.12 \pm 0.51$ & 0.6188 \\
\hline $\mathrm{Hgb}(\mathrm{g} / \mathrm{dL})$ & $11.12 \pm 2.89$ & $12.1 \pm 1.90$ & 0.00000225 \\
\hline T-Bil (mg/dL) & $2.1 \pm 1.4$ & $1.2 \pm 0.5$ & $<0.0000001$ \\
\hline Albumin(g/dl) & $5.8 .1 \pm 2.1$ & $3.1 \pm 1.87$ & 0.1768 \\
\hline $\operatorname{ALT}(\mathrm{U} / \mathrm{L})$ & $53.30 \pm 19.56$ & $28.1 \pm 18.14$ & 0.3812 \\
\hline AST(U/L) & $31.1 \pm 14.17$ & $24 \pm 6.1$ & $<0.0000001$ \\
\hline BMI $(\mathrm{kg} / \mathrm{m} 2)$ & $24.51 \pm 3.68$ & $22.14 \pm 2.11$ & $<0.0000001$ \\
\hline Adiponectin $(\mu \mathrm{g} / \mathrm{ml})$ & $9.23 \pm 4.19$ & $6.89 \pm 1.86$ & $<0.0000001$ \\
\hline Cholesterol (mg/dl) & $184.73 \pm 30.11$ & $179.1 \pm 27.34$ & 0.2613 \\
\hline HDL(mg/dl) & $49 \pm 14.1$ & $44.89 \pm 4.1$ & $<0.0000001$ \\
\hline LDL (mg/dl) & $94.190 \pm 43.690$ & $58.019 \pm 16.001$ & $<0.0000001$ \\
\hline VLDL & $36.1 \pm 4.1$ & $22.45 \pm 5.1$ & 0.007436 \\
\hline
\end{tabular}


Table 2: Comparison of BMI among the case and control groups with the other clinical parameters by taking male and female separately

\begin{tabular}{l|l|l|l|} 
& $\begin{array}{l}\text { STUDY } \\
\text { GROUP } \\
\text { BMI } \geq 25\end{array}$ & $\begin{array}{l}\text { CONTROL } \\
\text { GROUP } \\
\text { BMI } \leq 25\end{array}$ & P VALUE \\
\hline $\begin{array}{l}\text { Adiponectin } \\
(\mu \mathrm{g} / \mathrm{ml}) \\
\text { Male } \\
\text { Female }\end{array}$ & 60 & 79 & 0.0000127 \\
\hline $\begin{array}{l}\text { Cholesterol } \\
(\mathrm{mg} / \mathrm{dl})\end{array}$ & 38 & 14 & \\
$\begin{array}{l}\text { Male } \\
\text { Female }\end{array}$ & 54 & 44 & 0.00123 \\
\hline $\begin{array}{l}\text { HDL }(\mathrm{mg} / \mathrm{dl}) \\
\text { Male }\end{array}$ & 24 & 38 & 0.0057 \\
Female & 7 & 41 & \\
\hline $\begin{array}{l}\text { LDL }(\mathrm{mg} / \mathrm{dl}) \\
\text { Male }\end{array}$ & 38 & 49 & 0.85491 \\
Female & 19 & 27 & 0.76470 \\
\hline $\begin{array}{l}\text { VLDL } \\
\text { Male } \\
\text { Female }\end{array}$ & 58 & 68 & \\
\hline
\end{tabular}

Table 3: The quantitative values of adiponectin $(\mu \mathrm{g} / \mathrm{ml})$ among the different levels of viral loads in the HBV cases

\begin{tabular}{|l|l|}
\hline $\begin{array}{l}\text { Viral load(log } \\
\text { copies/ml) }\end{array}$ & $\begin{array}{l}\text { Adiponectin } \\
(\mu \mathrm{g} / \mathrm{ml})\end{array}$ \\
\hline$<60$ & 8.78 \\
\hline $60-200$ & 6.89 \\
\hline $200 \times 103$ & 10.58 \\
\hline $200 \times 103-200 \times 106$ & 13.87 \\
\hline$\geq 200 \times 106$ & 12.1 \\
\hline
\end{tabular}

Total bilirubin, ALT,BMI,HDL and LDL were found to be significantly associated with the disease $(p<0.05)$. From the Table 2 we can explain the viral load (log copies/ $\mathrm{ml}$ ) and the adiponectin levels among the HBV infected persons

Adiponectin is secreted by adipocytes which has a potent anti-inflammatory and ant diabetic properties and it can stimulate the insulin secretion, increase insulin sensitivity, and it has the capacity to control the obesity of a person (Diez, 2003; Berg, 2001; Kim, 2003). Hypoadiponectinemia is already reported its association with the metabolic syndrome. But, a little information has found till date about the role of adiponectin

\begin{tabular}{|l|l|l|l|l|}
\hline \multicolumn{5}{|l|}{$\begin{array}{l}\text { Table 4: The Genotypes and Allele Distribution of the adiponectin Gene } \\
\text { Polymorphisms in Case (with HBV) and Control Groups (without HBV). }\end{array}$} \\
\hline & Controls n=110 & Patients n=210 & OR(95\%CI) & p value \\
\hline rs2241766 & & & & \\
\hline TT & 47 & 63 & Ref & Ref \\
\hline TG & 38 & 104 & 2.03 & 0.008 \\
\hline GG & 25 & 43 & 1.28 & 0.4 \\
\hline Allele T & 132 & 230 & Ref & Ref \\
\hline Allele G & & & & \\
\hline & 88 & 251 & 1.63 & 0.002 \\
\hline rs1501299 & & & & \\
\hline GG & 64 & 134 & Ref & Ref \\
\hline GT & 38 & 69 & 1.78 & 0.01 \\
\hline TT & 8 & 7 & 0.86 & 0.7 \\
\hline Allele G & 166 & 337 & Ref & Ref \\
\hline Allele T & & & & \\
\hline & 54 & 83 & 0.7 & 0.16 \\
\hline rs266729 & & & & \\
\hline CC & 62 & 84 & Ref & Ref \\
\hline CG & 39 & 112 & 2.11 & 0.002 \\
\hline GG & 9 & 14 & 1.14 & 0.7 \\
\hline Allele C & 163 & 280 & Ref & Ref \\
\hline Allele G & 57 & 140 & 1.42 & 0.05 \\
\hline
\end{tabular}


Table 5: The relationship between serum adiponectin levels of case Vs control and the different genotypes of SNP rs1501299 and SNP rs266729

\begin{tabular}{|l|l|l|}
\hline rs1501299 Genotype & \multicolumn{2}{|c|}{ Adiponectin $(\mu \mathrm{g} / \mathrm{ml})$} \\
\hline & case & control \\
\hline CC & $10.4 \pm 0.34$ & $9.6 \pm 2.1$ \\
\hline CG & $6.1 \pm 1.20$ & $12.1 \pm 2.56$ \\
\hline GG & $4.8 \pm 1.8$ & $7.4 \pm 3.1$ \\
\hline rs266729 Genotype & & \\
\hline GG & $7.4 \pm 2.4$ & $9.3 \pm 1.46$ \\
\hline GT & $8.3 \pm 1.64$ & $6.1 \pm 3.12$ \\
\hline TT & $5.9 \pm 2.1$ & $12.6 \pm 1.98$ \\
\hline rs2241766 Genotype & & \\
\hline TT & $6.34 \pm 1.46$ & $4.1 \pm 2.1$ \\
\hline TG & $5.12 \pm 2.9$ & $7.23 \pm 3.4$ \\
\hline GG & $7.23 \pm 2.1$ & $5.34 \pm 1.98$ \\
\hline $\begin{array}{l}\text { The Adiponectin values were represented in mean } \\
\text { the case and control groups. }\end{array}$ \\
\hline
\end{tabular}

in patients with HBV infected liver diseases with different stages (Acute, Chronic, Cirrhosis, HCC and FHF). The effect of viral hepatitis (HBV) infection on the fatty liver disease was reported unclear. Hepatic steatosis in CHB patients was associated with host metabolic factors (Yilmaz et al., 2015).

In our study, we found the associative role of serum adiponectin in the patients with HBV infection, which can be considered as an agreement with the results of previous studies, (Buechler, Wanninger, Neumeier, 2011). Also it was found that the HDL,LDL and VLDL values were higher in cases than the control values. But only the HDL and LDL were significantly associated $(\mathrm{p}<0.05)$.

We also found that age is a significant factor of the study which is among the HBV-infected patients and the healthy control $(\mathrm{p}<0.05)$. But sex and INR is not found as a significant factor in this study $(\mathrm{p}>0.05)$. The basic screening along with LFT has showed that Hgb, T-Bil, AST has a significant association $(p<0.05)$. The BMI of the patients were found as higher than the control and

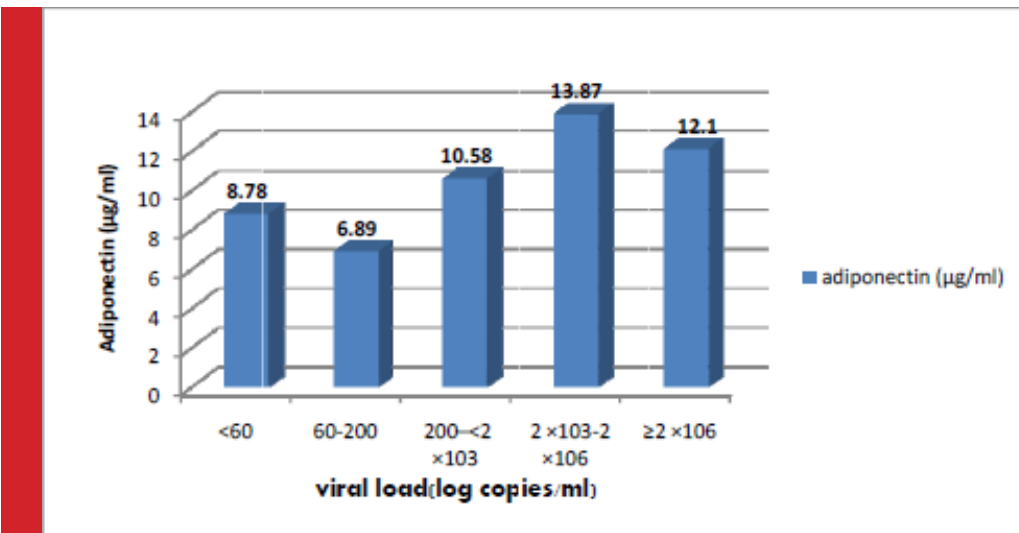

FIGURE 1: Bar diagram of Adiponectin $(\mu \mathrm{g} / \mathrm{ml})$ and viral load (log copies/ $\mathrm{ml}$ ) among the cases or HBV infected liver disease.
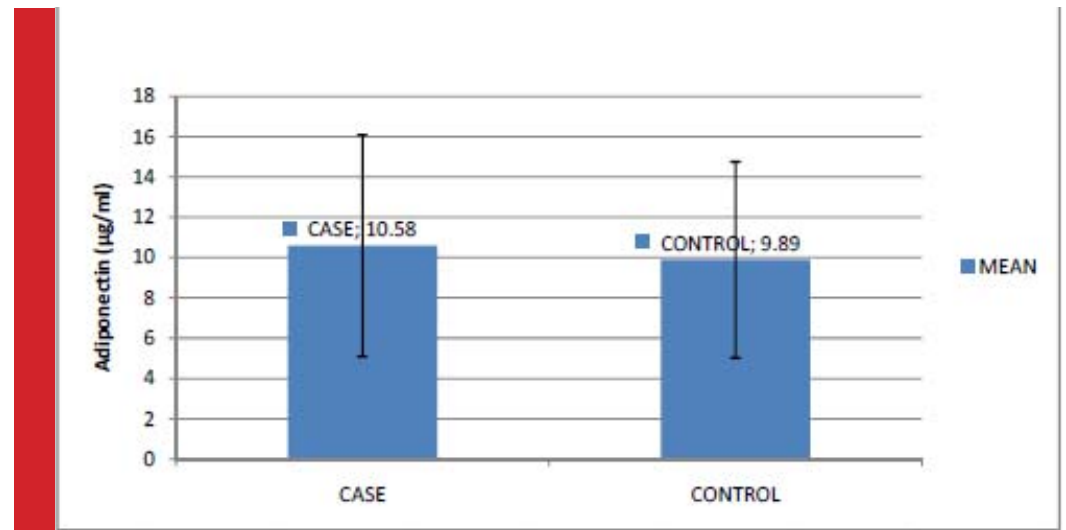

FIGURE 2: Mean \pm SD graph of case and control with compare the Adiponectin $(\mu \mathrm{g} / \mathrm{ml})$ values. 


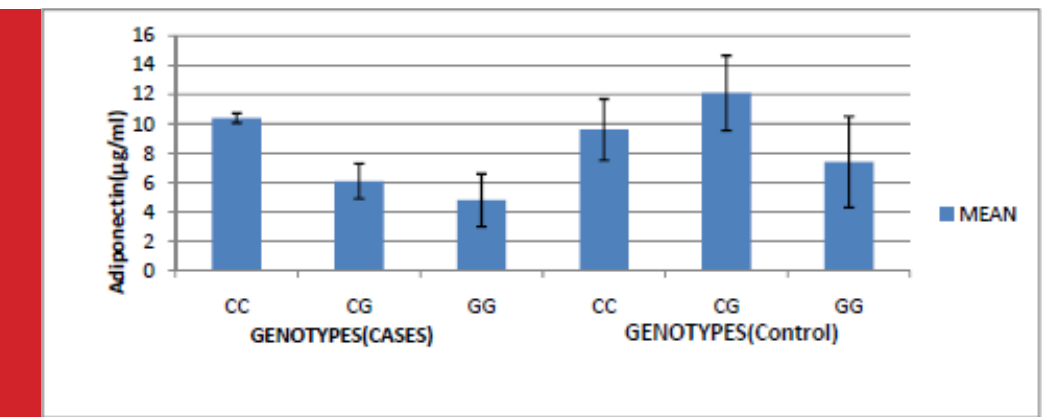

FIGURE 3: SNPrs1501299 Genotyps (CC/CG/GG) distribution among the cases and control and quantitative value of Adiponectin $(\mathrm{\mu g} / \mathrm{ml})$, which is significantly associated with the cases $(p<0.05)$.

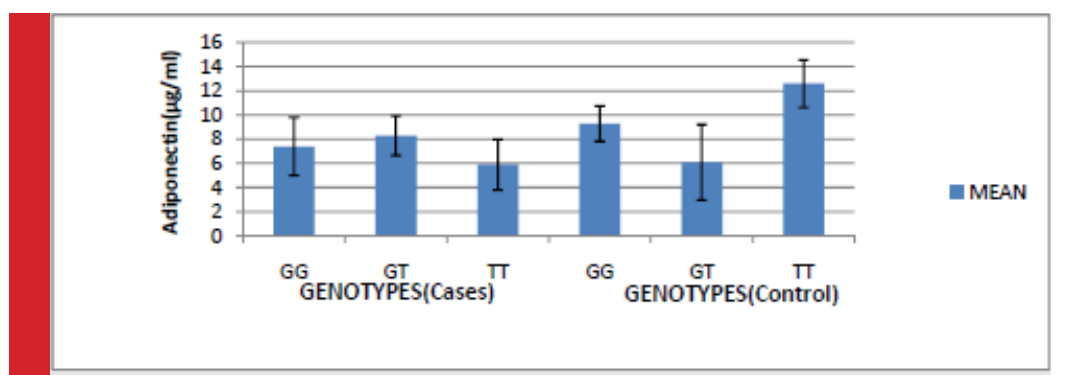

FIGURE 4: SNPrs266729 Genotype(GG/GT/TT) distribution among the cases and control and quantitative value of Adiponectin $(\mu \mathrm{g} / \mathrm{ml})$, which is significantly associated with the cases $(p<0.05)$.

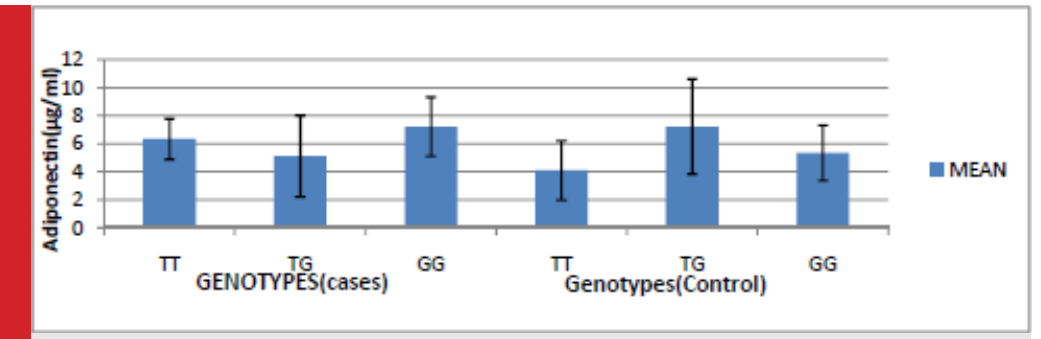

FIGURE 5: SNPrs rs2241766 Genotype (GG/GT/TT) distribution among the cases and control and quantitative value of Adiponectin $(\mathrm{\mu g} / \mathrm{ml})$, which is significantly associated with the cases $(\mathrm{p}<0.05)$.

were significantly associated ( $p<0.05)$. The BMI for the case was considered as $\geq 25$ and control group as $\leq 25$ in the Table 2 by considering the male and female numbers and compared the adiponectin, cholesterol, HDL, LDL and VLDL. Out of which adiponectin, cholesterol and HDL were found to be associated with high risk $(\mathrm{p}<$ 0.05). The controversy regarding the association between the presence of HBsAg and metabolic factors were further studied for better understanding understood from the HBV viral load values. Table 3 explains the distribution of the viral load (log copies/ml) and the adiponectin $(\mu \mathrm{g} / \mathrm{ml})$ values by considering the mean values only. The low adiponectin values were found in patients with viral load of 60-200 log copies/ml and the higher values of adiponectin were with viral load $2 \times 103^{-2} \times 106$. To further better understand the role of adiponectin in glucose metabolism a large sample size is needed to find the absolute significance.

\section{CONFLICTS OF INTEREST}

The authors declare no potential conflicts of interest relevant to this article. 


\section{ACKNOWLEDGMENTS}

This study was supported by a grant from the Bioengineering and Technology Department, Gauhati University, Assam, India.

\section{REFERENCES}

Berg AH, Combs TP, Scherer PE (2002) ACRP30/adiponectin: an adipokine regulating glucose and lipid metabolism. Trends Endocrinol Metab.13(2):84-9 .

Buechler C, Wanninger J, Neumeier M, et al (2011) Adiponectin, a key adipokine in obesity related liver diseases. World J Gastroenterol. 17:2801-2811.

Costa MC, Brito LL, Barbosa PJB, Ines L (2011) Adiponectina e baixo risco cardiometabólico em obesas. Arq Bras Endocrinol Metab.2(004-2730):55.

Diez JJ, Iglesias P (2003) The role of the novel adipocytederived hormone adiponectin in human disease. Eur J Endocrinol. 148:293-300.

Golsaz-Shirazi F, Shokri F.(2016) Hepatitis B immunopathogenesis and immunotherapy.Immunotherapy.8(4):461-77.

Hsu CS, Liu CH, Wang CC, Tseng TC, Liu CJ, Chen CL, Chen PJ, Chen DS, Kao JH (2012) Impact of hepatitis B virus infection on metabolic profiles and modifyingfactors. J Viral Hepat. 19(2):48-57.

Hsu CS, Liu WL, Chao YC, Lin HH, Tseng TC, Wang CC, Chen DS, Kao JH (2015) Adipocytokines and liver fibrosis stages in patients with chronic hepatitis B virus infection. Hepatol Int. 9(2):231-42. doi: 10.1007/s12072-015-9616-2.

Kaser S, Moschen A, Kaser A. (2005) Circulating adiponectin reflects severity of liver disease but not insulin sensitivity in liver cirrhosis. J Intern Med.258:274-280.
Kim MJ, Lee Y, Lee BJ. (2003) Plasma adiponectin concentration and insulin resistance in type 2 diabetes. J Korean Diabetes Assoc. 27:260-271.

Liu CJ, Chen PJ, Lai MY. (2009) High serum adiponectin correlates with advanced liver disease in patients with chronic hepatitis B virus infection. Hepatol Int . 3:364-370.

Lu JY, Chuang LM, Yang WS. (2005). Adiponectin levels among patients with chronic hepatitis B and C infections and in response to IFN-alpha therapy. Liver Int. 25:752759.

Marra F, Bertolani C (2009) Adipokines in liver diseases Hepatology. 50:957-969.

Pellme F, Smith U, Funahashi T, Matsuzawa Y, Brekke H, Wiklund 0, et al (2003).Circulating adiponectin levels are reduced in nonobese but insulin resistant first-degree relatives of type 2diabetic patients. Diabetes. 52(5):1182-6 .

Shields PG, Harris CC (1991). Molecular epidemiology and the genetics of environmental cancer. JAMA. 266:681-687.

Steppan CM, Lazar MA (2002). Resistin and obesity-associated insulin resistance. Trends Endocrinol Metab. 13(1):1823.

Tschritter 0, Fritsche A, Thamer C, Haap M, Shirkav and F, Rahe S. (2003).Plasma adiponectin concentrations predict insulin sensitivity of both glucose and lipid metabolism. Diabetes. 52(2):239-43.

WHO Expert Consultation (2004).Appropriate body-mass index for Asian populations and its implications for policy and intervention strategies. The Lancet 363:157-163.

Yilmaz B, Koklu S, Buyukbayram H, Yalçin K, Korkmaz U, Posul E, Can G, Kurt M (2015). Chronic hepatitis B associated with hepatic steatosis, insulin resistance,necroinflammation and fibrosis. Afr Health Sci. 15(3):714-8. 